Article

\title{
Issues Surrounding Behavior towards Discarded Textiles and Garments in Ljubljana
}

\author{
Katarina Polajnar Horvat ${ }^{1, *(1)}$ and Katarina Šrimpf Vendramin ${ }^{2}(\mathbb{C}$ \\ 1 Research Centre of the Slovenian Academy of Sciences and Arts, Anton Melik Geographical Institute, \\ 1000 Ljubljana, Slovenia \\ 2 Research Centre of the Slovenian Academy of Sciences and Arts, Institute of Slovenian Ethnology, \\ 1000 Ljubljana, Slovenia; katarina.srimpf@zrc-sazu.si \\ * Correspondence: katarina.polajnar@zrc-sazu.si; Tel.: +386-1-470-6545
}

Citation: Polajnar Horvat, K.; Šrimpf Vendramin, K. Issues Surrounding Behavior towards Discarded Textiles and Garments in Ljubljana.

Sustainability 2021, 13, 6491.

https://doi.org/10.3390/su13116491

Academic Editor: Grigorios

L. Kyriakopoulos

Received: 7 May 2021

Accepted: 1 June 2021

Published: 7 June 2021

Publisher's Note: MDPI stays neutral with regard to jurisdictional claims in published maps and institutional affiliations.

Copyright: (c) 2021 by the authors. Licensee MDPI, Basel, Switzerland. This article is an open access article distributed under the terms and conditions of the Creative Commons Attribution (CC BY) license (https:// creativecommons.org/licenses/by/ $4.0 /)$.

\begin{abstract}
In recent years, post-consumer textile waste has become an important issue that attracts attention from activists, scientists and the media. The production and use of clothing has more than doubled in the last fifteen years due to declining costs, streamlined operations and rising consumption under the influence of fast fashion. According to research, the average European buys as much as $26 \mathrm{~kg}$ of textiles each year and discards $11 \mathrm{~kg}$, while a very small share of post-consumer textile waste is recycled. This article presents the findings of a study on household textile waste in the capital of Ljubljana. The research showed that despite the significant declarative environmental awareness of people for sustainable behavior in the field of textile waste, the share of those decreases with exposure to actual behavior. However, there are few people who are completely uninterested in reducing textile waste, as most people are aware of the problem and pay more and more attention to it. The authors study the management of textile waste and its creation by the inhabitants of Ljubljana in the broader context of the influences of fast fashion, as well as the cultural specifics of the Slovenian society.
\end{abstract}

Keywords: textile waste; clothing; fast fashion; environmental awareness; environmental behavior; reuse

\section{Introduction}

Globally, the amount of waste is increasing rapidly [1]. Waste in general in the article is understood as a substance or object that the holder discards, intends to discard, or must discard [2]. With increasing urbanization, economic growth and population growth in the world, the World Bank predicts that the amount of waste generated will increase from 2.01 billion tons in 2016 to 3.40 billion tons in 2050 [3]. An individual produces on average 600 times as much waste as they weigh during their lifetime. However, the amounts of waste produced around the world vary considerably. Thus, only $16 \%$ of the world's population of the most developed countries produces as much as 34\% of the world's waste [3]. In Slovenia, for example, in 2019, each inhabitant produced an average of $509 \mathrm{~kg}$ of municipal waste, which is $10 \%$ more than in 2018 [4].

The amount of waste produced is directly related to wealth, production, and consumption [1,5]. People have more and more choice in consumption, and products have a shorter lifespan [1]. With the development of advertising, rapidly changing trends, and ever lower product prices, providers are inviting consumers to more intensive consumption and shopping. The changes in shopping habits and lifestyle may have increased the quality of our lives at first glance, but they also mean that we generate more waste than ever before [1].

What about textile waste in households? Textile waste in this article is defined as a material that is deemed unusable for its original purpose by the owner. It can include fashion and textile industry waste, created during fiber, textile, and clothing production, 
and consumer waste, created during consumer use and disposal [6]. According to the European Environment Agency, the production of clothing, footwear, and home textiles for personal consumption by Europeans is the fifth largest producer of $\mathrm{CO}_{2}$ emissions [7]. The current system of production, distribution, and use is almost entirely linearly linked to negative environmental and social impacts [8]. The production and use of clothing have more than doubled in the last fifteen years, due to declining costs, streamlined operations, and rising consumption under the influence of fast fashion [8]. At the European Union level, 9.35 million tons of textile waste are disposed of or incinerated each year [9]. Thus, the average European buys $26 \mathrm{~kg}$ of textiles every year and discards $11 \mathrm{~kg}$ [10]. In Slovenia, according to the Statistical Office for 2015 [4], the annual amount of textile and clothing waste ending up in mixed municipal waste from households is 37,180 tons. Thus, each inhabitant discards as much as $18 \mathrm{~kg}$ of textile waste per year. In this paper, we focus on people's attitudes towards textile waste in Slovenia and, in more detail, in its capital Ljubljana, and on the analysis of habits related to textile waste in households. We are interested in the behavior of the inhabitants of Ljubljana in relation to their awareness and handling of textiles. The theoretical framework explains how and why people dispose of textiles and what the reasons for their awareness, habits, and behavior related to textile waste are.

\section{Theoretical Background}

The production of clothing and textiles and their high consumption have a strong negative impact on people and the environment [11]. In 2016, per capita emissions related to the estimated global textile consumption were $442 \mathrm{~kg}$ of CO2eq, or $6.7 \%$ of global climate impacts $[12,13]$. The textile industry is one of the more environmentally burdensome and labor-intensive industries [11,14-16]. The production phase of textile represents one of the largest environmental impacts from the life-cycle perspective among other things, in terms of climate change, toxic pollutants, and contribution to water scarcity [13]. In Sweden, for example, the production phase includes approximately $80 \%$ of the total climate impact of the full life cycle of a textile. Similarly, the average European life cycle of production is $70 \%$, and the use-phase laundry is $10 \%$ of the total climate impact of the full life cycle of a textile $[13,17]$. However, the negative environmental impact is not only created by the industry itself, but also by consumer behavior, which generates large amounts of consumer textile waste.

The growing quantities of textiles in the global market, which are usually represented by lower quality and consequently cheaper fashion pieces, are associated with changes in consumer behavior. Although consumers spend a smaller share of their income on clothing, they buy more often and more fashion pieces $[18,19]$. These changes began in the late 1980s, and even more intensely in the late 1990s and early 21st century, when some brands, such as Zara and H\&M, established a shorter time chain from the design, through production, to the customer. This market model is called fast fashion [20,21].

Fast fashion is a business model where it is important that clothes are made quickly and cheaply, most often in third world countries (in Asia and Africa), based on the latest trends, allowing people to expand and refresh their wardrobe cheaply. In addition, many fashion retailers encourage more frequent purchases through impulse buying strategies when offering new collections every few weeks $[20,22,23]$. However, the concept of fast fashion has also led to the fact that, as research shows, consumers keep clothes only half the time they did 15 years ago. Consumers treat the cheapest clothes almost as disposable and discard them after only seven or eight uses [24]. During this time, the number of garments purchased by the average consumer per year increased by $60 \%$ [24].

Although the negative environmental impact of clothing, as much as $70 \%$, is generated in the course of production, the average European user in the life cycle of clothing creates, especially in the use phase, another $10 \%$ of emissions. However, one of the biggest challenges in the clothing life cycle, next to searching for cleaner models of production, is building up the infrastructure around collecting and sorting textiles for reuse and materials 
recycling [17]. Although textiles have a high potential for recycling, at a rate of $85 \%$ to $90 \%$, only between $1 \%$ and $43 \%$ are expected to be recycled [7,25]. At the EU level, between $15 \%$ and $25 \%$ of textile waste, both industrial and consumer, is collected separately and can then be reused or recycled [25]. The textile industry has been very late with its transition to a circular economy, in comparison to sectors such as plastics, glass, and metals [13]. Globally, it only uses 3\% of recycled materials. Although there are many initiatives under way, at the moment there is still no extended producer responsibility for the collection of textiles for reuse and recycling in most member states [17].

There is extremely little reuse of textiles in Slovenia, which is shown by the fact that there is practically no system for the separate collection of consumer textile waste. At the level of the city of Ljubljana, there are containers for separate collection of textile waste from the resell company Humana, in 56 places [26]. However, this is an entrepreneurial activity and not primarily a separate collection of textile waste or waste separation. The number of containers is decreasing from year to year, as the quality of the textiles is deteriorating, and their recycling technology is so demanding that collection centers across Europe limit their purchases due to the high costs of textile processing or disposal [27]. At the household level, the utility company Snaga d. o. o. does not yet offer the separate collection of textile waste, so residents often dispose of unusable textile waste as mixed waste [28]. Similar challenges are being encountered elsewhere in Europe. For example, in Sweden, according to 2016 data, only $1 \%$ of the total volume of textile consumed four years earlier was recycled. Also, most textiles ended up in unsorted household waste [17]. However, changes are expected soon, as the European Union has adopted the EU Directive 2018/851 as part of a package of measures on the circular economy, which requires EU member states to establish the separate collection of textiles in households by 1 January 2025 [29].

In addition to the issue of disposal, sales practices that promote consumerism and the rapid change of clothing are a major problem, as indicated by an increasing number of studies on the management of post-consumer textile waste [16,30-32]. Consumer behavior in terms of clothing maintenance, that is washing and drying, also has a significant environmental impact [33]. Until a few years ago, consumer behavior [34,35] was studied mainly in the context of marketing research, and less attention was paid to the processes and phases that lead to waste disposal, but this segment of research is also recently on the rise $[16,30,36,37]$. It is important to study consumer behavior from an environmental point of view, as they decide when, where, and in what way they will discard used clothes, thus determining their lifespan, the amount of waste generated, and the possibility of reuse and recycling [16], but also how they will handle the clothes in their lifespan, how many times they will be dressed, washed and dried. So what will be the consumption of electricity and water for their maintenance? Only the sum of all this information, about the production, transport, use of clothes, and their disposal, that is the life-cycle assessment or LCA, gives us information about their overall environmental impact [33].

\section{Methods}

Decisions about the selection and consumption of raw materials and their disposal in modern households take place behind closed doors, as noted by Daniel Miller [38]. Since it makes sense to research what is happening inside homes in the research of modern society, households are a key link in the waste production and consumption chain. Household members determine the choice of services and consumption of raw materials by their lifestyle, values, thinking, and behavior [39], while at the same time gross domestic product also plays an important role [40]. Compared to energy production and industry, an individual household has a relatively insignificant role in environmental impact, but if households in the whole country or municipality are considered, their combined impact is large [41]. Thus, the research was based on Miller's [38] recommendations and focused on observing and researching the behavior of individuals in their basic cells and households, namely, in the area of the City of Ljubljana. 
In the spring of 2020, we conducted an online survey for the primary form of insight into textile and clothing-related practices. We used an open source application, www.1ka.si (accessed on 1 February 2021) [42]. The online survey lasted for four months and was intended for the inhabitants of the whole of Slovenia, whereby we also separated the respondents according to which municipality they come from. In this study, we present an analysis of the habits of the inhabitants of the city of Ljubljana.

Although we are aware of the limitations, as we did not include a representative sample in the survey, this is the first survey of this kind in the Ljubljana area. We chose non-probability sampling because in recent years we have found it increasingly difficult to obtain a representative sample of the population, as people are less and less inclined to complete surveys. In addition, the study was conducted at a time of restrictions due to the COVID-19 epidemic, which made it impossible to address people directly, and thus contributed to the limitations by limiting access to representative samples. So, we decided to do the research online, with the widest possible public involved. On the other hand, by obtaining the answers of those who are interested in the topic, a deeper insight into the studied topic is gained, while non-interested parties are more likely to give socially desirable answers. Very similar results of the sample were later obtained in the all-Slovenia survey on discarded clothing, which was also conducted online in the autumn of 2020, with as many as 1371 answers [43].

Our survey was completed by 120 respondents. Among them, $81 \%$ were women and only $19 \%$ were men. The reason for the significant discrepancy in women's responses may be that women are the ones who handle textiles and related waste more often in households than men. In terms of age structure, most respondents were between 35 and 44 years old, namely, 34\%, followed by those aged between 25 and 34 at $24 \%$, aged 55 to 64 at $20 \%$, aged 45 to 54 at $18 \%$, and $2 \%$ aged 18 to 24 years and older than 65 years (see Figure 1).

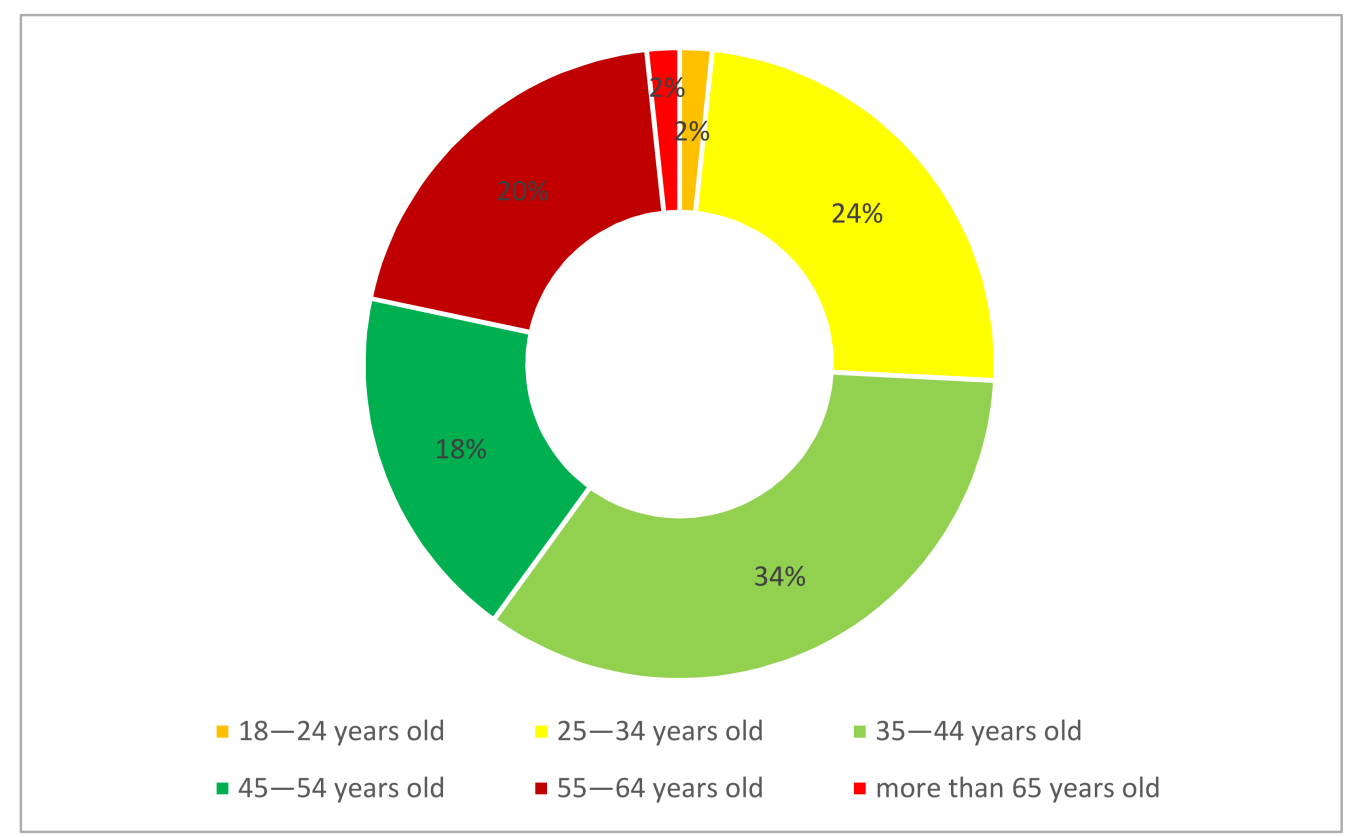

Figure 1. Age structure of respondents.

According to the educational structure, highly educated people predominate, namely, as many as $43 \%$ have a master's degree or a doctorate, $49 \%$ have a higher or university education, and only $8 \%$ have a secondary education. The survey was mainly responded to by an environmentally aware population (see Figure 2). 


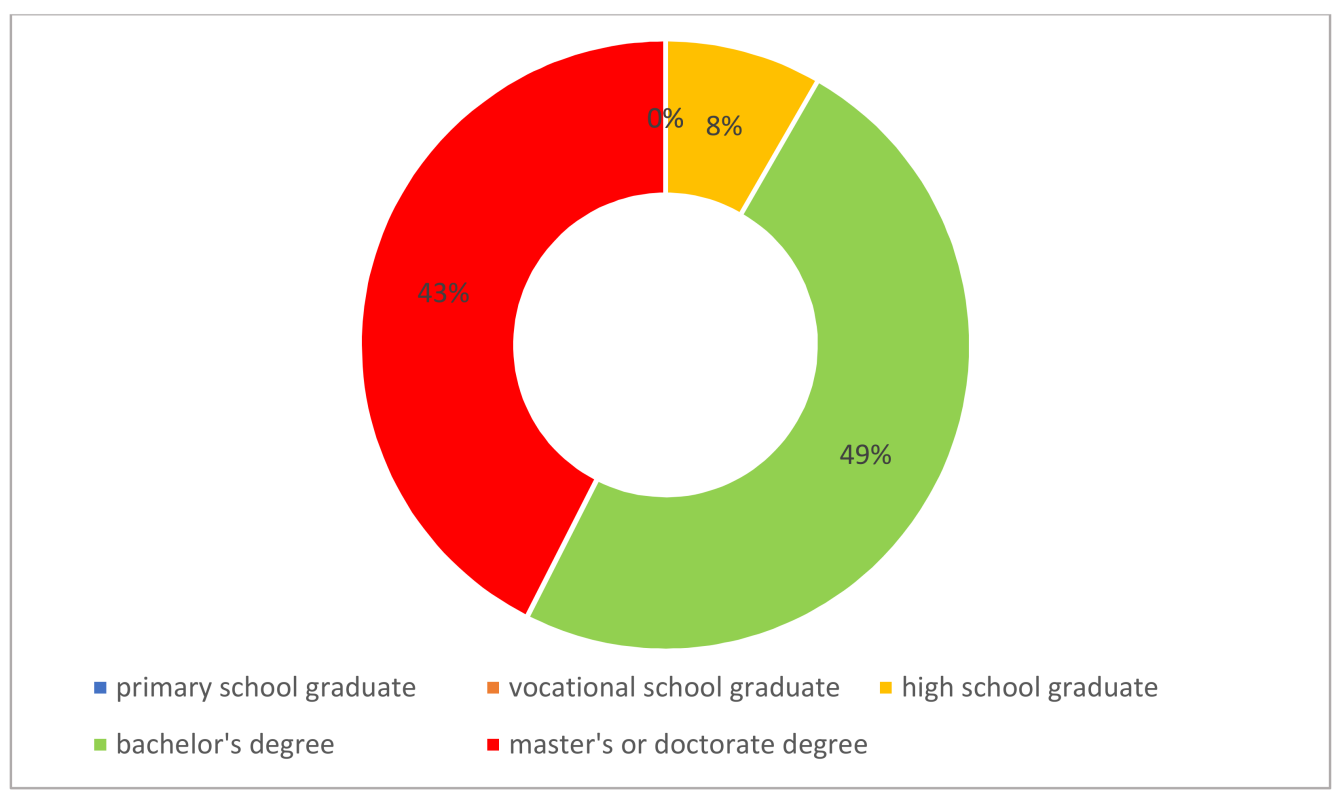

Figure 2. Educational structure of respondents.

The survey consisted of five systematic sets and 31 closed-ended and open-ended questions. The introductory part was intended to study the state of general environmental awareness of respondents and awareness of textile waste and its disposal. For these questions, we used the Likert scale from 1 to 5, with 1 meaning "I am not aware at all" and 5 "I am very aware". This was followed by a course on handling clothing, shoes, and home textiles. This part was intended to study the actions related to the purchase, disposal, separate collection, or use of worn-out clothing. We were also interested in the feelings of discarding textiles, and at the end, a set of demographic questions followed.

\section{Results}

The results showed a high level of declarative general environmental awareness of the respondents, with the mean value of the answers being 4.2. However, when we concretized the topic and asked the respondents about their awareness of textile waste, they showed a lower level of awareness, with an average value of 3.6 (see Table 1).

Table 1. Status of general environmental awareness and awareness regarding textile waste.

\begin{tabular}{|c|c|c|c|c|c|c|c|c|}
\hline Question & $\begin{array}{c}\text { I Am } \\
\text { Not Aware } \\
\text { at All }\end{array}$ & $\begin{array}{c}\text { I Am } \\
\text { Not } \\
\text { Aware }\end{array}$ & $\begin{array}{l}\text { I Am } \\
\text { Partly } \\
\text { Aware }\end{array}$ & $\begin{array}{l}\text { I Am } \\
\text { Aware }\end{array}$ & $\begin{array}{c}\text { I Am } \\
\text { Very } \\
\text { Aware }\end{array}$ & Total & $\bar{x}$ (Mean) & $\begin{array}{l}\text { Standard. } \\
\text { Deviation }\end{array}$ \\
\hline $\begin{array}{l}\text { To what extent do you feel you } \\
\text { are environmentally aware? }\end{array}$ & $\begin{array}{c}0 \\
0 \%\end{array}$ & $\begin{array}{c}0 \\
0 \%\end{array}$ & $\begin{array}{c}11 \\
9 \%\end{array}$ & $\begin{array}{c}79 \\
66 \%\end{array}$ & $\begin{array}{c}30 \\
25 \%\end{array}$ & $\begin{array}{c}120 \\
100 \%\end{array}$ & 4.20 & 0.57 \\
\hline $\begin{array}{c}\text { To what extent do you feel } \\
\text { aware of textile waste? }\end{array}$ & $\begin{array}{c}1 \\
1 \%\end{array}$ & $\begin{array}{c}6 \\
5 \%\end{array}$ & $\begin{array}{c}45 \\
38 \%\end{array}$ & $\begin{array}{c}53 \\
44 \%\end{array}$ & $\begin{array}{c}15 \\
13 \%\end{array}$ & $\begin{array}{c}120 \\
100 \%\end{array}$ & 3.60 & 0.80 \\
\hline
\end{tabular}

The reason for the gap between general environmental awareness and awareness among textile waste is that the issue of textile waste has come to the fore only in recent years and people are not yet sufficiently aware of it. In addition, neither at the state nor the municipality level is textile waste collected separately, and people usually do not even think about it. The respondents buy on average 11 to 20 pieces of new clothing per year at $41 \%$, followed by those who buy 5 to 10 pieces of clothing at $23 \%, 21$ to 50 pieces at $19 \%$, more than 50 pieces only at $5 \%$ of respondents, and $12 \%$ of respondents who buy less than 5 pieces of new clothes (see Figure 3). They most often buy underwear and socks at $81 \%$ and cotton T-shirts at $49 \%$. 


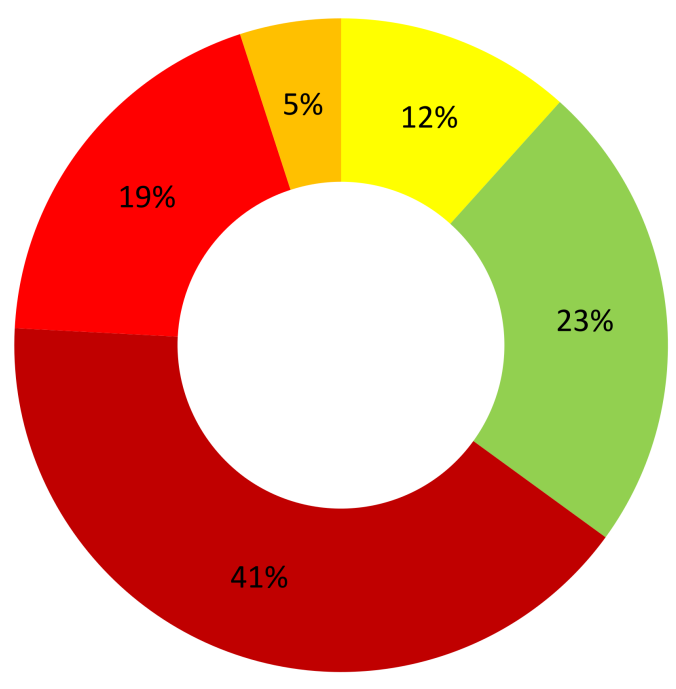

(less than 5)

(from 5 to 10 )

(from 11 to 20)

- (from 21 to 50$)$

(more than 50)

Figure 3. Number of newly purchased pieces of clothing per year.

As many as $45 \%$ of the respondents buy most of their clothes new, but they are also given some or buy used ones. It should be noted that the majority of respondents live in a multi-member household where children are present, and in this regard accept or buy used clothes. This is also indicated by the answer that $17 \%$ of the respondents rarely buy new clothes, where most of them are donated. On the other hand, $36 \%$ of the respondents always buy new clothes. The need of the majority of Slovenes to buy new clothes was also perceived by the ethnologist Mateja Habinc [44], when she studied reasons why there are so few second-hand clothing shops in Slovenia. She found that new clothing in Slovenia is still ahead of used clothing, where the focus is on originality, uniqueness, nostalgia, or environmental awareness, which are common in Western Europe and North America $[44,45]$. She saw the reason for such an attitude towards buying second-hand clothes in the cult of the new, which was spread by mass socialist consumerism, which, among other things, equated buying second-hand clothes with poverty [44]. On a positive note, the respondents rarely throw clothes into mixed waste, at only $14 \%$. They are most often taken to a Humana container with $63 \%$, donated to friends, or acquaintances at $56 \%$ or the Red Cross, Caritas at $49 \%, 26 \%$ are processed or otherwise recycled, and $17 \%$ are taken to the collection center of the utility company (see Figure 4). Among mixed waste, the respondents, although very rarely, most often discard socks and underwear. Those who re-use textiles most often use them for cleaning cloths, mending children's clothes, gardening, and the like.

The respondents on average throw away 5 to 10 garments a year, most commonly cotton T-shirts, and underwear and socks. The fact that the inhabitants of Ljubljana are quite rational in creating consumer textile waste shows that as many as $52 \%$ of the respondents themselves repair minor damage to clothing (e.g., small holes, tears, dropped buttons), and thus extend their lifespan. Thus, the most common reasons for discarding clothes are their wear and tear $(86 \%)$.

Other clothing and textile items, such as shoes and home textiles, account for a very small share of post-consumer textile waste. Thus, the respondents buy an average of one to three pairs of shoes per year. If they do not wear shoes, most often due to age, and wear and tear, they are most often dumped into the mixed waste. Very rarely, the respondents discard shoes because they no longer like them, are out of fashion, or because of the need for space. It has also been shown that people take shoes to a shoemaker quite often, $28 \%$ take them always, and $23 \%$ often but not always. The respondents rarely buy home textiles, less than 
every year at $53 \%$, and $37 \%$ buy 1 to 5 pieces a year, most often buying bedding, followed by bathroom towels and kitchen towels. Home textiles are very rarely discarded, less than one piece per year. They are discarded due to wear and tear, and are most often reused for cleaning cloths.

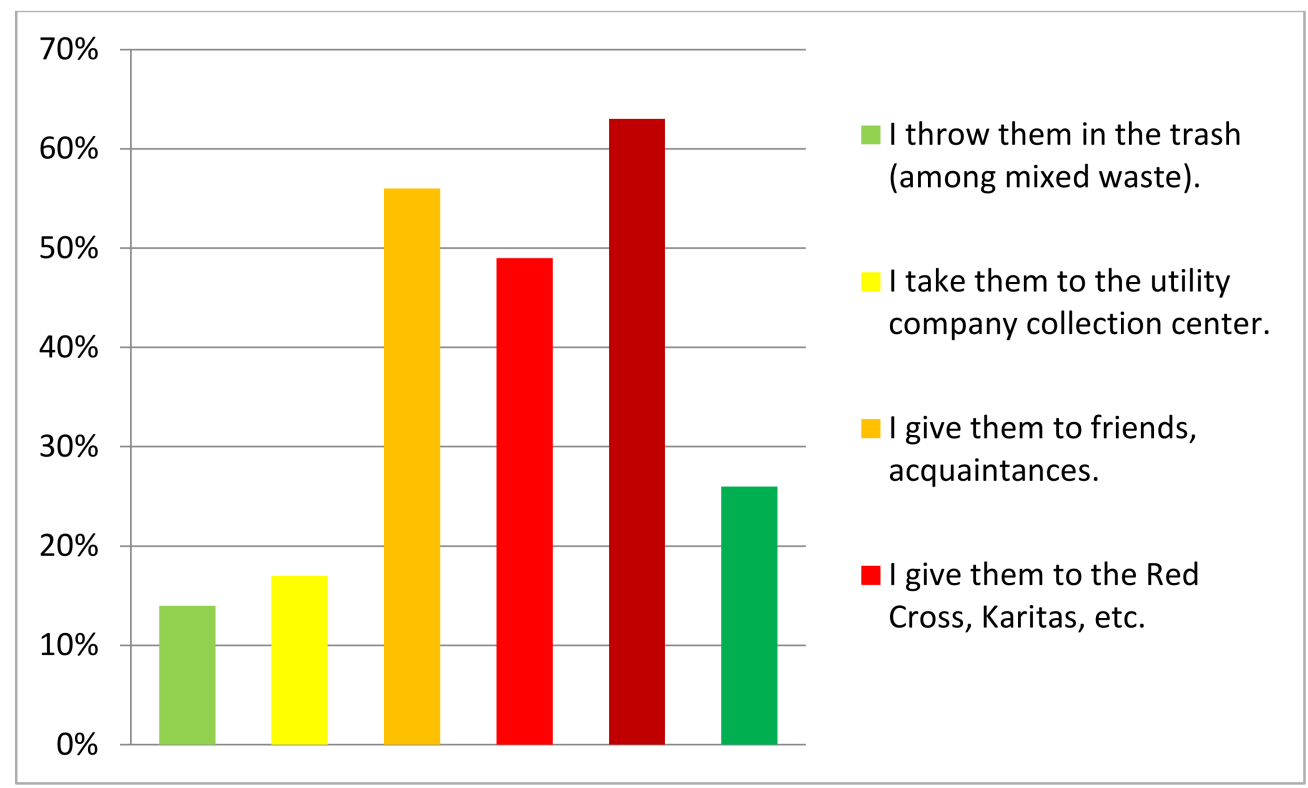

Figure 4. The most common fate of clothing when discarded (multiple answers possible).

From the point of view of textile purchases, the respondents show modern trends in behavior, and quite often buy new pieces of clothing, shoes, and other forms of textiles. One of the reasons can be seen in the fact that today's product promotion is extremely strong, and often the desire to buy prevails over the rationality of the decision. However, they are also attracted by the low prices of the textile items, as consumers feel that they have made a good bargain by buying cheap clothing [46]. Although one of the drivers of fast fashion is the rapid adaptation to trends [20,23], it is interesting that only a very small proportion (only 5\%) of the respondents expressed an intention to buy new clothes due to fashion motives, which is extremely encouraging from the environmental point of view.

Regarding feelings when discarding textiles, the respondents did not express excessive bad conscience, as they discard them only when they are already completely useless. As many as $40 \%$ of the respondents expressed mixed feelings that today's textiles are of much lower quality compared to textiles in the past. They are saddened by the thought that quality textiles are practically impossible to buy nowadays, which is also one of the effects of the spread of fast fashion, where other aspects such as following trends are more important than product quality [47]. On the other hand, the respondents expressed a high level of responsibility in terms of disposing of textile waste after its use. Namely, the respondents throw away textiles only after they are completely useless, and most of the time they reuse them for cleaning cloths. The reason for this may be that we are dealing with the interested public, who are well aware of the handling of textiles and are motivated to solve this type of problem. On the other hand, the cause can also be found in the roots of past clothing management practices, when clothing was considered economical, extended with patching and processing, and wearing clothes while they were still usable $[48,49]$.

\section{Discussion}

In Ljubljana, despite the considerable declarative environmental awareness of people for sustainable behavior in the field of textile waste, we found that the share of actual environmental awareness decreases with exposure to actual behavior in practice. A similar conclusion was reached in other studies. It was found that personal norms and the 
moral nature of motivations to reduce clothing consumption are those that otherwise have a significant impact on behavioral purposes related to reducing clothing consumption. However, on the other hand, because of their connection to people's visual perception of each other, clothing is particularly exposed and influenced by social norms. Also, due to the prevailing marketing technique and advertising that promotes the purchase of new clothes, and following the changing trends, otherwise good intentions of reducing the consumption of clothes are often more difficult to achieve in practice [50].

The sense that awareness of the importance of reducing textile waste is increasing gives us the fact that there are few people who are completely uninterested in reducing textile waste, as people are mostly aware of the problem and pay more and more attention to it. This is especially important, as research shows that most of us do not wear as much as $50 \%$ of the clothes we have at home [32]. This suggests that consumption in the clothing segment is much higher than the actual needs of individuals, and consumer textile waste creates major environmental problems as very few textiles are reused [25].

Wider social progress in the field of textile waste management can be increased through information provision, that is education and training of other consumers, so that their choices will influence the decisions of retailers in the direction of reducing textile waste, as well as creating a more socially and environmentally ethical textile industry.

On the other hand, the successful shift to a circular economy could be also one of the key solutions to meet the sustainable development goals. At the moment, there are many efforts to optimize the current system of production of textiles and garments, but the shift to a circular system for textiles needs a systematic change throughout the whole chain of textiles, and also changes in policies. To improve efficiency and reduce environmental degradation, the technological innovation is not enough, but complex social innovation and advancement in terms of working conditions, equality and social justice are also needed. There is also a need for a change to new business models and policies, which can reach extended life time, which could be the easiest environmental earning [51].

In recent years, we have witnessed radical changes in the field of waste management in the city of Ljubljana, both in terms of systemic changes and changes in people's minds [52]. The residents have reduced the amount of landfill waste and are also separating it to a greater extent. Although still largely at the expense of financial savings and due to the force of infrastructural changes, the share of those who separate for environmental reasons is growing. However, as our research has shown, very little or almost nothing has been done at the national and city level, unlike other types of waste, in relation to consumer textile waste. For example, at the household level by Snaga d. o. o., there is no separate collection of textile waste, and the population is not encouraged to do so. The problems related to waste can be completely specific, so we cannot solve them only with universal approaches, but the solutions must be adapted to the socio-cultural environment and the actual needs of people. Researches also show that the efficacy of communication about environmental issues is better if the information is content specific, that is, it addresses, for example, how much water and energy can be saved through the reduction in one's personal clothing consumption. So, more impact is achieved when consumers are directly addressed with information about the impact of their behavior on the environment [50].

Although our research has some weaknesses, such as a small sample of respondents, reliance on self-reported purchasing and disposal behaviors, which are subject to several potential biases, including memory bias (e.g., inaccurate reporting of purchase amounts) and social desirability bias (e.g., deliberate underreporting of purchases), or lack of in-depth research of the behavior of Slovenian costumers, this research represents an important step in the research of consumer behavior in connection with textile waste in Slovenia. In further research, it is therefore important to further address consumer behavior, explore the importance of other variables that influence purchase and use behavior that are not assessed in the current study, and compare them with research results from other countries. In any case, this research already reveals some aspects that help us better understand the specifics of the Slovenian consumers. 


\section{Conclusions}

Our research has shown that there is much room for improvement in the sustainable management of consumer textile waste in Ljubljana, especially in the direction of its reduction and prevention, and especially in the direction of raising consumer awareness of the social and environmental consequences of affordable clothing and textiles waste in general. Thus, based on the conducted research, we recommend promoting a bottom-up approach through a policy of small steps. With methods of practical approach, adapted to the individual or community, we can achieve better understanding and awareness, which leads to appropriate changes in practice [53]. One of the effective ways to have a long-term positive impact on behavior change is the implementation of targeted information and education through the education system and curricula, while research shows that young people are more receptive to innovations and represent the most effective medium for transmitting such ideas and practices to the elderly [52,54]. On the other hand, research shows that young people are the most affected in the fast fashion market model, as teenagers, whose money is generally quite limited, love the concept of very cheap clothes and are proud of the fact that their fashionable clothes cost a little. Low clothing prices, achieved by manufacturers through various mechanisms, however, allow them to change their styles quickly, despite low financial resources [46,47]. As a result, almost the entire fast fashion market, along with all marketing support, has become youth-oriented [11]. Thus, it is crucial that young people start raising awareness about the creation and management of consumer textile waste.

Author Contributions: Conceptualization, K.P.H. and K.Š.V.; methodology, K.P.H. and K.Š.V.; software, K.P.H. and K.Š.V.; validation, K.P.H. and K.Š.V.; formal analysis, K.P.H. and K.Š.V.; investigation, K.P.H. and K.Š.V.; resources, K.P.H. and K.Š.V.; data curation, K.P.H. and K.Š.V.; writing—original draft preparation, K.P.H. and K.Š.V.; writing-review and editing, K.P.H. and K.Š.V.; visualization, K.P.H. and K.Š.V.; supervision, K.P.H. and K.Š.V.; project administration, K.P.H. and K.Š.V.; funding acquisition, K.P.H. and K.Š.V.; funding acquisition. Both authors have read and agreed to the published version of the manuscript.

Funding: This research was funded by the Slovenian Research Agency as part of the research program Geography of Slovenia (P6-0101), Cultural Spaces and Practices: Ethnology and Folklore Studies (P6-0088) and the research project Invisible Life of Waste: Development of an Ethnography-Based Solution for Waste Management in Households (L6-9364).

Informed Consent Statement: Informed consent was obtained from all subjects involved in the study.

Data Availability Statement: Data available on request due to restriction of privacy.

Conflicts of Interest: The authors declare no conflict of interest.

\section{References}

1. Podjed, D.; Polajnar Horvat, K. The invisible life of food waste: The case of Ljubljana households. Tradition 2020, 49, 109-124. [CrossRef]

2. Waste Management. Available online: https://www.stat.si/statweb/File/DocSysFile/8272 (accessed on 14 April 2021).

3. Kaza, S.; Yao, L.C.; Bhada-Tata, P.; van Woerden, F. What a Waste 2.0: A Global Snapshot of Solid Waste Management to 2050; Urban Development; World Bank Publications: Washington, DC, USA, 2018.

4. Waste. Available online: https://www.stat.si/StatWeb/Field/Index/13/70 (accessed on 1 February 2021).

5. Smrekar, A.; Valjavec, M.B.; Polajnar Horvat, K.; Tiran, J. The geography of urban environmental protection in Slovenia: The case of Ljubljana. Acta Geogr. Slov. 2019, 59, 8-80. [CrossRef]

6. The Ecochic Design Award Sourcing Textile Waste. Available online: https://static1.squarespace.com/static/582d0d16440243165 eb756db/t/585a15a9bebafba69927c172/1482298805626/LEARN2014_Sourcing_ENG-07.pdf (accessed on 24 May 2021).

7. Private Consumption: Textiles EU's Fourth Largest Cause of Environmental Pressures after Food, Housing, Transport. 2019. Available online: https:/ / www.eea.europa.eu/highlights/private-consumption-textiles-eus-fourth-1 (accessed on 1 February 2021).

8. What's New in Clothing Recycling? 2020. Available online: https://www.livingcircular.veolia.com/en/industry/whats-new-in -clothing-recycling (accessed on 1 February 2021).

9. A New Circular Economy Concept. 2018. Available online: http://www.resyntex.eu/images/downloads/RESYNTEX-Leaflet2018.pdf (accessed on 1 February 2021). 
10. Textiles in Europe's Circular Economy. 2019. Available online: https://www.eea.europa.eu/themes/waste/resource-efficiency/ textiles-in-europe-s-circular-economy (accessed on 1 February 2021).

11. Anguelov, N. The Dirty Side of the Garment Industry: Fast Fashion and Its Negative Impact on Environment and Society; Routledge: Boca Raton, FL, USA, 2016.

12. Measuring Fashion. Environmental Impact of the Global Apparel and Footwear Industries Study. Available online: https://quan tis-intl.com/wp-content/uploads/2018/03/measuringfashion_globalimpactstudy_full-report_quantis_cwf_2018a.pdf (accessed on 24 May 2021).

13. Sandin, G.; Ross, S.; Spak, B.; Zamani, B.; Peters, G. Environmental Assessment of Swedish Clothing Consumption-Six Garments, Sustainable Futures; RISE Ab: Götheburg, Sweden, 2019.

14. Beckert, S. Empire of Cotton: A Global History; Vintage Books: New York, NY, USA, 2014.

15. Thomas, D. Fashionopolis the Price of Fast Fashion and the Future of Clothes; Head of Zeus: New York, NY, USA, 2019.

16. Nencková, L.; Pecáková, I.; Šauer, P. Disposal behaviour of Czech consumers towards textile products. Waste Manag. 2020, 106, 71-76. [CrossRef] [PubMed]

17. Östlund, A.; Roos, S.; Sweet, S.; Sjöström, E. Investor Brief: Sustainability in Textiles and Fashion; The Swedish Foundation for Strategic Environmental Research: Stockholm, Sweden, 2020.

18. Nordås, H.K. The Global Textile and Clothing Industry Post the Agreement on Textiles and Clothing; World Trade Organization: Geneva, Switzerland, 2004; Available online: https:/ / www.wto.org/english/res_e/booksp_e/discussion_papers5_e.pdf (accessed on 1 February 2021).

19. Joy, A.; Sherry, F.J.; Venkatesh, A.; Wang, J.; Chan, R. Fast fashion, sustainability, and the ethical appeal of luxury brands. Fash. Theory 2012, 16. [CrossRef]

20. Ghemawat, P.; Iniesta, J.L.N. ZARA: Fast Fashion; Harvard Business Publishing: Boston, MA, USA, 2003; Available online: https:/ / hbsp.harvard.edu/product/703497-PDF-ENG?Ntt=Zara\&itemFindingMethod=Search (accessed on 1 February 2021).

21. Bhardwaj, V.; Fairhurst, A. Fast fashion: Response to changes in the fashion industry. Int. Rev. Retail Distrib. Consum. Res. 2010, 20. [CrossRef]

22. McAfee, A.; Dessain, V.; Sjöman, A. Zara: IT for Fast Fashion; Harvard Business Publishing: Boston, MA, USA, 2004; Available online: https:/ / store.hbr.org/product/zara-it-for-fast-fashion/604081 (accessed on 1 February 2021).

23. Choi, T.; Liu, S.; Tsang, T.K.L.; Zheng, J. Service quality strategy for fast fashion: An empirical study in Hong Kong. In Fast Fashion Systems: Theories and Applications; Tsan-Ming, C., Ed.; CRC Press: Boca Raton, FL, USA, 2014; pp. $129-140$.

24. Remy, N.; Speelman, E.; Swartz, S. Style That's Sustainable: A New Fast-Fashion Formula; McKinsley Sustainability: New York, NY USA, 2016; Available online: https:/ / www.mckinsey.com/business-functions/sustainability / our-insights/style-thats-sustaina ble-a-new-fast-fashion-formula\# (accessed on 1 February 2021).

25. Filho, W.L.; Ellams, D.; Han, S.; Tyler, D.; Boiten, V.; Paço, A.; Moora, H.; Balogun, A.-L. A review of the socio-economic advantages of textile recycling. J. Clean. Prod. 2019, 218. [CrossRef]

26. Humana. Available online: https:/ / www.humana.si/copy-of-r-osrednjeslovenska-regija (accessed on 1 February 2021).

27. Nieboer, H. Kam Izginjajo Zabojniki za Zbiranje Oblačil? 2019. Available online: https:/ / ebm.si/prispevki/kam-izginjajo-zaboj niki-za-zbiranje-oblacil (accessed on 1 February 2021).

28. Waste. 2021. Available online: https:/ / www.vokasnaga.si/odpadki (accessed on 1 February 2021).

29. European Parliament and Commission. Direktive (EU) 2018/851. 2018. Available online: http://data.europa.eu/eli/dir/2018/85 1/oj (accessed on 1 February 2021).

30. Laitala, K. Consumers' clothing disposal behaviour-A synthesis of research results. Int. J. Cons. Stud. 2014, 38. [CrossRef]

31. Nørup, N.; Pihl, K.; Damgaard, A.; Scheutz, C. Quantity and quality of clothing and household textiles in the Danish household waste. Waste Manag. 2019, 87. [CrossRef] [PubMed]

32. Zhang, L.; Wu, T.; Liu, S.; Jiang, S.; Wu, H.; Yang, J. Consumers' clothing disposal behaviors in Nanjing, China. J. Clean. Prod. 2020, 276. [CrossRef]

33. Sohn, J.; Nielsen, K.S.; Birkved, M.; Joanes, T.; Gwozdz, W. The environmental impacts of clothing: Evidence from United States and three European countries. Sustain. Prod. Consum. 2021. [CrossRef]

34. Becker-Leifhold, C.; Heuer, M. Eco-Friendly and Fair: Fast Fashion and Consumer Behaviour; Routledge: Milton, UK, 2018.

35. Rathinamoorthy, R. Sustainable Fashion: Consumer Awareness and Education; Muthu, S.S., Ed.; Springer: Berlin/Heidelberg, Germany, 2018.

36. Hetherington, K. Secondhandedness: Consumption, disposal, and absent presence. Environ. Plan. D 2004, 22. [CrossRef]

37. Bianchi, C.; Birtwistle, G. Consumer clothing disposal behaviour: A comparative study. Int. J. Consum. Stud. 2012, 36. [CrossRef]

38. Miller, D. Home Possessions. Material Culture behind Closed Doors; Routledge: Milton, UK, 2001.

39. Selan, A.T. Household Budget Survey and Household Spending Patterns in Slovenia and the European Union. Master's Thesis, University of Ljubljana, Ljubljana, Slovenia, 2006.

40. European Commission. Economic Accounts of the European Union; Panorama of the European Union; European Commission: Luxembourg, 1999.

41. Vukadin, B.; Burja, A.; Kušar, U. Potrošnja v gospodinjstvih: Število in velikost gospodinjstev. In Kazalci Okolja v Sloveniji; Ministry of Environment: Ljubljana, Slovenia, 2011; Available online: http:/ / kazalci.arso.gov.si / ?data=indicator\&ind_id=348 (accessed on 1 February 2021). 
42. Splošen Opis. 2021. Available online: https://www.1ka.si/d/sl/o-1ka/splosen-opis (accessed on 1 February 2021).

43. Nieboer, H.; Sreš, K.; Zorko, B.; Kranjc, J. Obleka Naredi Človeka: Rezultati Vseslovenske Raziskave o (Odvrženih) Oblačilih; Zavod za Pravično Trgovino, 3MUHE: Ljubljana, Slovenia, 2021; Available online: http:/ /www.oblekanaredicloveka.si/wp-content/uplo ads /2021/03/ONC-raziskava_small.pdf (accessed on 24 May 2021).

44. Habinc, M. Izjemnost trgovanja z rabljenimi oblačili v (sodobni) Sloveniji? Gaz. Sloven. Ethno. Soc. 2016, 56, 321-343.

45. Appelgren, S.; Bohlin, A. Introduction: Circulating stuff through second-hand, vintage and retro markets. J. Curr. Cult. Res. 2015, 7. [CrossRef]

46. Gabrielli, V.; Baghi, I.; Codeluppi, V. Consumption practices of fast fashion products: A consumer-based approach. J. Fash. Mark. Manag. 2013, 17. [CrossRef]

47. Bruce, M.; Daly, L. Buyer behavior for fast fashion. J. Fash. Mark. Manag. 2006, 10, 329-344.

48. Žagar, J. Oblačilna Kultura Delavcev v Ljubljani Med Prvo in Drugo Svetovno Vojno; Mladika: Ljubljana, Slovenia, 1994.

49. Makarovič, M. Obleka Predela Človeka: Oblačilna Kultura v Kmečkem Okolju na Severu in Jugovzhodu Štajerske od 18. do 20. Stoletja; Litera: Maribor, Slovenia, 2007.

50. Joanes, T.; Gwozdz, W.; Klöckner, C. Reducing personal clothing consumption: A cross-cultural validation of the comprehensive action determination model. J. Environ. Psychol. 2020, 71, 1-10. [CrossRef]

51. Manshoven, S.; Christis, M.; Vercalsteren, A.; Arnold, M.; Nicolau, M.; Lafond, E.; Mortensen, L.F.; Coscieme, L. Textiles and the Environment in a Circular Economy. Eionet Report. 2019. Available online: https://ecodesign-centres.org/wp-content/uploads /2020/03/ETC_report_textiles-and-the-enviroment-in-a-circular-economy.pdf (accessed on 31 May 2021).

52. Polajnar Horvat, K. Environmentally Friendly Behavior; Georitem 26: Ljubljana, Slovenia, 2015.

53. Polajnar Horvat, K. The efficacy of social influence in environmental awareness and behaviour regarding water. Geogr. Vestn. 2017, 89, 37-49. [CrossRef]

54. Kovačič, G.; Grubar, V.B. Knowledge of sustainable development among geography students in Slovenia. Acta Geogr. Slov. 2016, 56. [CrossRef] 